\title{
Risk factors associated with cystic echinococcosis in humans in selected pastoral and agro-pastoral areas of Uganda
}

\author{
Emmanuel Othieno ${ }^{1}$, Andrew Livex Okwi ${ }^{1}$, Ezekiel Mupere ${ }^{1}$, Eberhard Zeyhle ${ }^{2}$, Peter Oba ${ }^{3}$, Martin Chamai ${ }^{3}$, \\ Leonard Omadang ${ }^{3}$, Francis Olaki Inangolet ${ }^{4}$, Ludwing Siefert ${ }^{3}$, Francis Ejobi ${ }^{3}$ and Michael Ocaido ${ }^{3}$
}

\begin{abstract}
1. School of Biomedical Sciences, College of Health Sciences, Makerere University, P.O. Box 7072, Kampala, Uganda; 2. Hydatid Disease Unit, African Medical and Research Foundation, P.O. Box 30125, Wilson Airport, Langata Road, Nairobi 00100, Kenya; 3. School of Veterinary Medicine and Animal Resources, College of Veterinary Medicine, Animal Resources and Biosecurity, Makerere University, P.O. Box 7062, Kampala, Uganda; 4. Napak District Veterinary Office, Karamoja, Uganda.

Corresponding author: Emmanuel Othieno, e-mail: othienoemma@yahoo.com, Co-authors: ALO: andrewol@chs.mak.ac.ug,EM: mupez@yahoo.com,EZ: zeana07@yahoo.de, PO: dobaat2@gmail.com, MC: mchamai@yahoo.com, LO: omadangleonard@gmail.com, FOI: drinangolet@yahoo.com, LS: ludwing siefert@yahoo.com,FE: ejobifrancis@gmail.com, MO: mocaido@yahoo.com
\end{abstract}

Received: 29-09-2016, Accepted: 01-02-2017, Published online: 26-02-2017

doi: 10.14202/IJOH.2017.1-6 How to cite this article: Othieno $E$, Okwi AL, Mupere $E$, Zeyhle $E$, Oba $P$, Chamai $M$, Omadang L, Inangolet FO, Siefert L, Ejobi F, Ocaido M. Risk factors associated with cystic echinococcosis in humans in selected pastoral and agro-pastoral areas of Uganda. Int J One Health 2017;3:1-6.

\begin{abstract}
Aim: It was to determine the risk factors responsible of occurrence of cystic echinococcosis (CE) of humans in the pastoral and agro-pastoral (PAP) in Uganda.

Materials and Methods: A cross-sectional study was conducted in districts: Moroto, Napak, Nakapiripirit and Amudat in Karamoja region; in agro-pastoral communities of Teso region, in the districts of Kumi and Bukedea; Nakasongola district in Central region and in Kasese district in the Western region. People were subjected to voluntary ultrasound screening for $\mathrm{CE}$. Those found positive to $\mathrm{CE}$ on ultrasound screening were interviewed using a special designed form to find out the probable predisposing factors for acquisition of CE infection. Predisposing factors considered were location, age, sex, dog ownership, occupation, water source, and religion. Univariate and multivariate logistic regression analysis was performed to identify key risk factors.
\end{abstract}

Results: In Karamoja region, being female, age beyond 40 years and open spring water sources were the risk factors. While for Nakasongola age beyond 40 years was a risk factor. In Kasese dog ownership, age $>60$ years and being a Muslim were risk factors. In Teso region dog ownership and age $>60$ years were the risk factors.

Conclusion: Being a pastoralist, a female, increasing age beyond 40 years, open spring water sources, dog ownership and being a Muslim were the risk factors for CE in PAP areas in Uganda.

Keywords: agro-pastoral, cystic echinococcosis, humans, risk factors pastoral, Uganda.

\section{Introduction}

Echinococcosis is an endemic zoonotic infection found throughout the developing world $[1,2]$. It is a neglected emerging and re-emerging disease [3]. Cystic echinococcosis (CE) is caused by infection with the larval stage of the tapeworm Echinococcus granulosus. The definitive hosts of this parasite are carnivores which are infected when they ingest the organs of herbivores that contain hydatid cysts of this worm. The cysts of this worm once ingested develop into adult tapeworms in the carnivores. Infected carnivores shed this worm eggs in their feces which contaminate the soil, water, and food. The intermediate hosts the herbivores and humans get infected by ingesting this tapeworm eggs in contaminated objects.

Copyright: Othieno, et al. This article is an open access article distributed under the terms of the Creative Commons Attribution 4.0 International License (http://creativecommons.org/licenses/ by/4.0/), which permits unrestricted use, distribution, and reproduction in any medium, provided you give appropriate credit to the original author(s) and the source, provide a link to the Creative Commons license, and indicate if changes were made. The Creative Commons Public Domain Dedication waiver (http:// creativecommons.org/ publicdomain/zero/1.0/) applies to the data made available in this article, unless otherwise stated.
Once ingested by herbivores and humans, the eggs hatch and develop into cysts called hydatid cysts in their internal organs. The disease caused in humans is called hydatidosis. In humans, hydatidosis is most commonly found in people involved in raising herbivores together with carnivores mainly dogs which are allowed access to eat the tissues of herbivores containing hydatid cysts. Therefore, a high prevalence of $\mathrm{CE}$ has been associated with the pastoral communities such as Turkana, Toposa, Nyangatom, Hamar and Boran [4,5]. Pastoral and agro-pastoral (PAP) areas in Uganda present conditions likely to favor occurrence of CE among humans in Uganda. The WHO lists Uganda as one of the countries with high endemicity of CE [6]. However, there is not much information of CE situation in Uganda. A retrospective study conducted from 1967 to 1972 [7] found 23 cases of echinococcosis among the Karimojong, Lango, and Acholi people in Uganda. In another study [8], an average of 20 surgical cases per year has been seen in hospitals in Karamoja and Mbarara regions in Uganda. An earlier preliminary survey using ultrasound [8] found a prevalence of hydatidosis of $0.4 \%$ 
$(n=7)$ among 1605 people screened. Among the wild animals examined on postmortem in Queen Elizabeth National Park, Uganda, hydatidosis was found in $33.3 \%$ of lions, $10.4 \%$ of warthogs, and $17.2 \%$ of buffaloes [9]. Furthermore, hydatidosis had been reported in impala and goats in Lake Mburo National park [10]. In dogs, the prevalence of E. granulosus of $66.3 \%$ $(n=217)$ had been reported on autopsy in Moroto district in Uganda [11].

A recent study done by Othieno et al. [12] in PAP areas in Uganda showed a prevalence of CE of 3.32\% in Central Karamoja, $1.21 \%$ in Teso region, $2.15 \%$ in Kasese and $2.7 \%$ in Nakasongola districts, in Uganda on ultrasound screening. However, the risk factors for occurrence of CE in these areas were not known. The knowledge of risk factors for occurrence of CE is important for designing of practical appropriate measures for controlling CE in humans these areas.

It is against the above background that studies were done with the aim to determine which risk factors were associated with the occurrence of $\mathrm{CE}$ in humans in these areas.

\section{Materials and Methods}

Ethical approval

Permission and ethical approval was sought from Uganda's Ministry of Health Research Council and Makerere University College of Health Sciences Ethical and Institutional Review Board. Visitations to the selected districts were made to get permission from District leaders. District leaders and communities at the village level were earlier informed about the intended exercise. Through the district medical officers, district health inspectors, local leaders and village health committees, the volunteers were mobilized among communities in selected sub-counties, parishes and villages, respectively. Health centers IV, III or II were selected as screening areas. On the day of screening, discussions were first held with participants, explaining the purpose for screening. A portable ultrasound machine powered by a portable generator was used for screening. Designed forms were used to capture data from consented adults or assented guardians for the minors who participated in the study. Volunteers were assured of free diagnosis.

\section{Methodology}

A cross-sectional A survey was conducted from 2012 to 2014. The ultrasound screening for CE was done in the districts: Moroto, Napak, Nakapiripirit and Amudat in Karamoja region, Teso region in the districts of Kumi and Bukedea; Nakasongola district in central region and in Kasese district in the Western region. These districts were purposively selected to represent PAP areas in Uganda. A total number of 3636 volunteers were screened as shown in Table- 1 .

In a well-lit room, volunteers were asked to lie on the examination couch and expose the entire chest and abdomen. Examination gel was applied to the abdominal skin and an ultrasound examination probe. The entire
Table-1: Distribution of people ultrasound screened for hydatidosis based on sex and region.

\begin{tabular}{lcccc}
\hline Regions & Males & Females & Total & Ratio (M.F) \\
\hline $\begin{array}{l}\text { Karamoja (North } \\
\text { East) }\end{array}$ & 580 & 1113 & 1693 & $1: 1.9$ \\
Teso (East) & 134 & 610 & 744 & $1: 4.6$ \\
Nakasongola & 166 & 429 & 595 & $1: 2.6$ \\
(Central) & & & & \\
Kasese (West) & 437 & 167 & 604 & $1: 0.4$ \\
Total & 1317 & 2319 & 3636 & $1: 1.8$ \\
\hline
\end{tabular}

abdominal cavity was scanned in four basic planes as described as transverse, sagittal, oblique subcostal and coronal supra-costal planes [13]. Those found positive were further interviewed using a special designed form to find out the probable predisposing factors for acquisition of CE infection which was a dependent variable. Predisposing factors (independent variables) considered for those who had CE were type of livestock production system, age, sex, dog ownership, occupation, water source, and religion. Variable considered according to the type of livestock production system was being pastoral or agro-pastoral. Pastoral areas were considered to be Karamoja region, Nakasongola district, and Kasese district. While Teso region was considered to be agro-pastoral area. For age to be considered as a risk factor, age groups were categorized into the following strata: below 20 years, 21-40 years, 41-60 years and $>60$ years. Variables considered for occupation was one being pastoralist, agro-pastoralist, business person, and having formal or informal employment. Water sources were categorized as being from the well, spring, bore hole, rivers, lake, dams, pools, and tap water. Religions considered were being a Catholic, Protestant, Pentecostal, any other Christian sects, Muslim, and Traditionalist.

\section{Statistical analysis}

Data were entered into Excel 16.0 and analyzed using R statistical software version 3.1.2 (The R Core Team, 2014). Univariate and multivariate logistic regression analysis was performed to identify the key risk factors for the occurrence of $\mathrm{CE}$ among those who were found positive on ultrasound scanning. The relationship between the risk factors and occurrence of CE was examined at $95 \%$ confidence interval. Variables of values of $p<0.05$ of less likeness of association with CE presence were considered statistically significant. Multivariate logistic regression analysis was performed per region on those variables which were found to have a significant association with $\mathrm{CE}$ occurrence on univariate analysis.

\section{Results}

There was a CE prevalence of $0.5 \pm 0.3 \%$ in South Karamoja (Amudat and Nakapiripirit districts), $3.32 \pm 1.3 \%$ in Central Karamoja (Napak and Moroto districts), $1.21 \pm 0.8 \%$ in Teso region, $2.15 \pm 1.2 \%$ in Kasese region, and $2.7 \pm 1.3 \%$ in Nakasongola region.

Pastoral areas (Karamoja, Nakasongola, and Kasese) had a very highly significantly $\left(X^{2}=2342\right.$; 
$\mathrm{p}<0.001)$ more $\mathrm{CE}$ in humans $2.73 \%(\mathrm{CI}=2.0-3.4)$ than in agro-pastoral areas of Teso $(1.2 \%(\mathrm{CI}=0.4-2.0)$.

The univariate logistic regression analysis for CE risk factors in different regions was as shown in Table-2. Multivariate logistic regression analysis for the key risk factors for $\mathrm{CE}$ in different regions was as shown in Table-3.

In Karamoja, the prevalence of CE significantly varied with district of origin of respondent. Moroto and Napak districts had significantly higher prevalence of CE infection $(p<0.05)$ than Amudat and Nakapiripirit. Nakapiripirit had a significantly lower CE prevalence $(0.46 \%)$ than the overall mean $(1.7 \%)$ for Karamoja. In Karamoja, significant differences in infection status exist among different age groups. Risk of CE infection increased with age. Age was identified to be a significant risk factor for $\mathrm{CE}$ infection. The use of springs as water sources increased the risk of $\mathrm{CE}$ infection by 2.8 times (Odds ratio $[\mathrm{OR}]=2.8$ ) compared to other sources of water. Females were
2.69 times more likely to test positive (be infected) for $\mathrm{CE}$ than males $\left(\mathrm{X}^{2}=3.89, \mathrm{p}<0.05\right)$. Multivariate logistic regression analysis on key risk factors (age, sex, water sources) for the occurrence of CE in Karamoja region was as shown in Table-3.

In Nakasongola region, univariate analysis showed advanced age $>40$ to be associated with increased risk of CE infection (Table-2). Those $>60$ years of age were about 11 times $(\mathrm{OR}=10.9)$ more likely to be positive for $\mathrm{CE}$ than those aged 21-40 years of age, while those between 41 and 60 years were about 7 times $(\mathrm{OR}=6.9)$ more likely to be CE-positive than those between 21 and 40 years of age. Although not statistically significant, males were found to be about 2 times $(\mathrm{OR}=2.05)$ more likely to be positive for $\mathrm{CE}$ than females. Multivariate logistic regression analysis for key risk factors for the occurrence of CE (age beyond 40 years) in Nakasongola was as shown in Table-3.

In Teso region (Bukedea and Kumi), univariate logistic regression analysis showed occurrence

Table-2: Univariate logistic regression analysis for significant risk factors for occurrence of CE in different pastoral and agro-pastoral areas.

\begin{tabular}{|c|c|c|c|c|c|}
\hline Region & Risk factor & Number examined & $\begin{array}{c}\text { Percentage CE } \\
\text { prevalence }\end{array}$ & OR ( $95 \% \mathrm{CI})$ & p value \\
\hline \multirow[t]{5}{*}{ Karamoja region } & Age $41-60$ & 383 & 3.4 & $2.0(0.96-4.10)$ & $0.0417 *$ \\
\hline & Age $<60$ & 80 & 5.0 & & $0.031 *$ \\
\hline & Sex: Being female & 1138 & 2.28 & $2.69(1.03-7.03)$ & $0.0433 *$ \\
\hline & Sex: Male & 580 & 0.9 & & \\
\hline & Water source being spring & 368 & 4.3 & $2.61(1.07-5.77)$ & 0.0173 \\
\hline \multirow[t]{4}{*}{ Nakasongola region } & Age $41-60$ & 96 & 7.2 & $2.8(0.96-7.5)$ & $0.0297 *$ \\
\hline & Age $<60$ & 33 & 13.7 & $4.96(1.14-16.77)$ & $0.0169 *$ \\
\hline & Sex: Being male & 166 & 4.2 & $2.05(0.9-3.2)$ & $0.063^{\mathrm{NS}}$ \\
\hline & Sex: Females & 429 & 2.1 & & \\
\hline \multirow[t]{4}{*}{ Teso region } & Age $<60$ & 76 & 5.26 & $4.52(0.99-16.7)$ & $0.025 *$ \\
\hline & Dog ownership & 196 & 3.57 & $10.09(1.89-100.42)$ & $0.0018 * *$ \\
\hline & Sex: Being male & 134 & 2.23 & $2.30(0.2-3.4)$ & $0.058^{\mathrm{NS}}$ \\
\hline & Sex: Females & 610 & 0.98 & & \\
\hline \multirow[t]{3}{*}{ Kasese region } & Age $<60$ & 16 & 6.25 & $3.2(0.07-25.02)$ & $0.038^{*}$ \\
\hline & Dog ownership & 207 & 5.3 & $11.07(2.38-103.77)$ & $0.0002 * * *$ \\
\hline & Being a Muslin (religion) & 41 & 9.7 & $4.89(1.10-16.88)$ & $0.0183 *$ \\
\hline
\end{tabular}

$\mathrm{NS}=\mathrm{p}>0.05$ not significant, $* \mathrm{p}<0.05$ significant, $* * \mathrm{p}<0.01$ highly significant, $* * * \mathrm{p}<0.001$ very highly significant.

$\mathrm{CE}=$ Cystic echinococcosis, $\mathrm{OR}=$ Odds ratio, $\mathrm{CI}=$ Confidence interval

Table-3: Multivariate logistic regression analysis for significant risk factors for CE in different pastoral and agro-pastoral areas.

\begin{tabular}{llcccc}
\hline Region & Variable & OR & SE & Z value & p value \\
\hline Karamoja region & Intercept coefficient & 499,884 & 0.723 & 7.88 & $3.34 \mathrm{e}-15^{* * *}$ \\
& Age 40-60 & 122.46 & 0.768 & 2.718 & $0.0066^{* *}$ \\
& Age<60 & 405.6 & 0.878 & 2.972 & $0.0021^{* *}$ \\
\multirow{4}{*}{ Nakasongola region } & Water source being spring & 10.8 & 0.448 & 2.309 & $0.02^{*}$ \\
& Intercept coefficient & 40,271 & 0.711 & 6.481 & $0.15 \mathrm{e}-11^{* * *}$ \\
& Age 40-60 & 235.5 & 0.830 & 2.856 & $0.0043^{* *}$ \\
Teso region & Age<60 & 540.7 & 0.780 & 2.860 & $0.0086^{* *}$ \\
& Intercept coefficient & 14,856 & 0.843 & 4.950 & $7.42 \mathrm{e}-07^{*}$ \\
& Age<60 & 47 & 0.787 & 2.106 & $0.0352^{*}$ \\
Kasese region & Dog ownership & 120.5 & 0.814 & 2.558 & $0.0105^{*}$ \\
& Intercept coefficient & $12.59 e 91$ & 1.357 & 6.024 & $17 \mathrm{e}-09^{* * *}$ \\
& Age<60 & 402.7 & 0.233 & 2.598 & $0.0037^{* *}$ \\
& Dog ownership & 121.34 & 0.800 & 2.605 & $0.0092^{* *}$ \\
& Being a Muslin (religion) & 114.3 & 0.750 & 2.743 & $0.0061^{* *}$ \\
\hline
\end{tabular}

$* \mathrm{p}<0.05$ significant, $* * \mathrm{p}<0.01$ highly significant, $* * * \mathrm{p}<0.001$ very highly significant. $\mathrm{SE}=$ Standard error, $\mathrm{CE}=\mathrm{Cystic}$ echinococcosis, $\mathrm{OR}=$ Odds ratio 
CE infection was associated with dog ownership and advanced age $>60$ years (Table-2). Those $>60$ years were more likely to be positive for $\mathrm{CE}(\mathrm{OR}=4.5)$ than other age groups of respondents. Dog ownership associated significantly with increased risk of CE infection $(\mathrm{OR}=10)$. Although not statistically significant, males were found to be about 2.27 times $(\mathrm{OR}=2.3)$ more likely to be positive for $\mathrm{CE}$ than females. Multivariate logistic regression analysis for key risk factors (age, dog ownership) for the occurrence of CE in Teso region (Bukedea and Kumi) was as shown in Table-3.

In Kasese region, univariate logistic regression analysis for CE risk factors showed that there was association of prevalence of $\mathrm{CE}$ with age $>60$ years, dog ownership and being a Muslim were significantly associated with increased likelihood of CE infection. Multivariate logistic regression analysis for key risk factors (age, dog ownership, and being a Muslim) for occurrence of CE in Kasese region was as shown in Table-3.

The variation $\mathrm{CE}$ prevalence with age in different regions in Uganda was as shown in Figure-1. The percentage of households owning dogs according to regions was as shown in Table-4. There was high proportion of households keeping dogs in Karamoja than Teso $\left(\chi^{2}=68.4, \mathrm{p}<0.001\right)$ and Nakasongola region $\left(\chi^{2}=35.6, \mathrm{p}<0.001\right)$.

\section{Discussion}

This study has shown that pastoral areas of Karamoja, Nakasongola, and Kasese had very highly

Table-4: Percentage of households owning dogs according to regions.

\begin{tabular}{lccc}
\hline Regions & $\begin{array}{c}\text { Total } \\
\text { number of } \\
\text { households }\end{array}$ & $\begin{array}{c}\text { Households } \\
\text { owning } \\
\text { dogs }\end{array}$ & $\begin{array}{c}\text { Percentage of } \\
\text { households } \\
\text { owning }\end{array}$ \\
\hline $\begin{array}{l}\text { Karamoja } \\
\text { region }\end{array}$ & 722 & 465 & 64.4 \\
$\begin{array}{l}\text { Teso region } \\
\text { Nakasongola }\end{array}$ & 745 & 216 & 29 \\
region & 408 & 132 & 32.4 \\
\hline
\end{tabular}

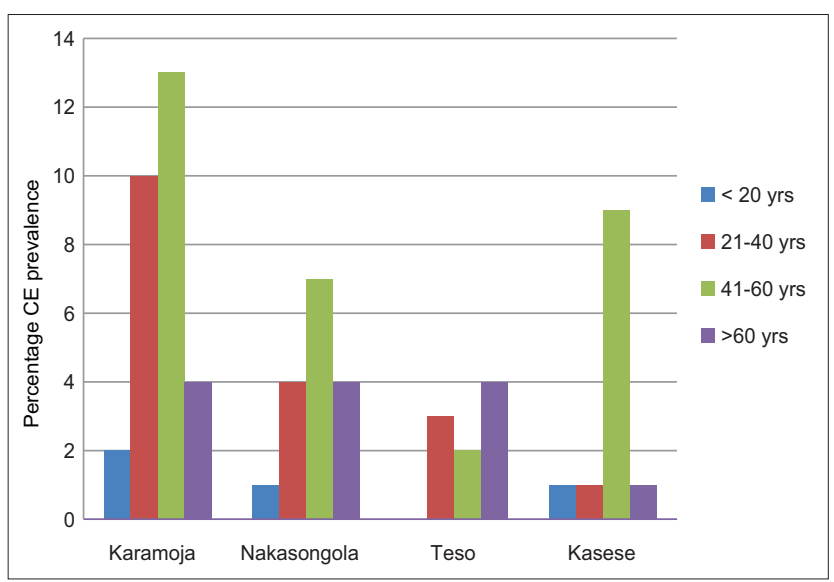

Figure-1: Variation of cystic echinococcosis prevalence with age in various regions. significant more $\mathrm{CE}$ infection prevalence in humans than in agro-pastoral areas of Teso region. Pastoralism and herding have been found to be risk factors for prevalence of CE elsewhere. Pastoralism has been a risk factor for the occurrence of $\mathrm{CE}$ among the Turkana in Kenya, Toposa and Bouya people in Sudan, and Nyangatom in Ethiopia [4]. Higher prevalence of $\mathrm{CE}$ has been reported among nomadic Tibetan communities in China [14-16]. Earlier on pastoralism had been reported as risk factor for $\mathrm{CE}$ among pastoralists in Kasese district, Uganda [17,18]. This could be explained by the fact that among pastoralist, livestock keeping was the major activity. Dog-human-livestock interactions were intensive among these communities. Dogs were often kept for security reasons $[15,19,20]$.

It was found that $\mathrm{CE}$ prevalence increased with age in all districts with more vulnerable age being age beyond 60 years (Table-2 and Figure-1). In Karamoja, there was clear positive linear trend of increase of CE prevalence with age with the disease appearing at all age groups including those aged below 20 years (Figure-1). Whereas, in Nakasongola and Kasese CE significant first appearance was among those beyond age of 40 years. On contrary, in Teso the disease first appeared among those beyond 60 years. In all districts, $\mathrm{CE}$ prevalence was most prevalent among those beyond 60 years. Nakasongola had a highest CE prevalence among those who were beyond the age of 60 years. These findings agreed with what had been observed elsewhere among animal keepers in Denizil, Turkey [21] communities in Ningxia Hui Autonomous Region in China [19,22], among Tibetans in China $[15,16]$ and in Central Ethiopia [23]. This finding was also consistent with the findings in Thessaly region, Central Greece [24] where humans beyond age 65 were significantly associated with seropositivity to $\mathrm{IgG}$ antibodies to E. granulosus. The high chances of being infected with $\mathrm{CE}$ increased with age this could be attributed to increased exposure to worm eggs over a long period. A study similar to this was conducted in Kyrgyzstan and arrived at the same conclusion [25]. Furthermore, the age-dependent increment in infection rate of $\mathrm{CE}$ is supported by apparent lack of parasite-induced immunity of naturally infected hosts [14] therefore a chance of getting infected with increasing age is summative.

Karamoja region showed sexual dimorphism to the prevalence of $\mathrm{CE}$, with females having a significantly higher prevalence than males (Table-2). This finding was similar to what had been observed among Turkana, in Kenya [26-28]. Elsewhere similar findings have been reported [15,19,21-23]. This could be due to fact that women were more likely to get in contact with feces of dogs because their daily chores involved activities like fetching water, fruit and vegetable picking, tilling of land to grow crops, weeding of crops, eating of raw tubers like cassava and potatoes without washing and plastering of houses with mud. However, attempts have been made to clarify the role 
of sexual dimorphism in CE susceptibility by carrying out experimental infections of mice with hydatidosis [29]. It was demonstrated that feminine hormones (estradiol) could be facilitating success of establishment of CE infection.

Although not statistically significant, in Teso and Nakasongola regions, males were 2.3 and 2.1 times respectively (Table-2) more likely to have $\mathrm{CE}$ than females. This could be attributed to the fact males have intimate relationship with dogs especially during hunting expeditions and as security guards as they move with their livestock during dry season.

Unprotected open spring water sources have been shown to be a risk factor in occurrence of CE in Karamoja (Table-2). These water sources were shared with livestock and dogs. Intensity of sharing water increases during water shortage periods during the dry season and drought. The Karamojong practice transhumance form of pastoralism, in which livestock moved and concentrated in a few watering points available during dry periods. A similar situation had been observed in Chinese families where there was unique clustering of $\mathrm{CE}$ in Ningxia Hui Autonomous Region [1,22] and among Tibetans, China [14-16]. Elsewhere water source as being a risk for $\mathrm{CE}$ has been reported among Turkana $[4,30]$.

Dog ownership was found to be a risk factor in Kasese and Teso region. On contrary in Nakasongola, dog ownership was not shown as risk factor among those who were infected with CE. Dog ownership has been reported as a risk factor of CE among Turkana, Kenya [4,30,31], the Chinese communities [14-16,19,22] and in Morocco [32]. In Kasese and Teso region, the households owning dogs were few as compared to those in Karamoja (Table-4), there was a positive correlation between those having $\mathrm{CE}$ and those owning dogs. Earlier studies [17,18] reported dog ownership to be a risk factor for $\mathrm{CE}$ in Kasese district. On contrary, in Karamoja region, there was no correlation between those having $\mathrm{CE}$ and those owning dogs. This was because there was high proportion of households owning dogs; hence, there was no significant difference in proportion of households owning dogs both in CE infected and CE non-infected households. This means that dog ownership was a risk factor for CE in Karamoja which could not be elucidated by the statistical analysis performed. A recent study [20] reported a prevalence of E. granulosus of $14.4 \%$ using copro-polymerase chain reaction of among dogs in Moroto district, Karamoja region. On postmortem, the prevalence of $66.3 \%$ had earlier on been reported among dogs in Karamoja [11]. E. granulosus infection risk factors for dogs in Karamoja have been reported to be as free access to slaughter places including home slaughter, high livestock populations and lack of knowledge about epidemiology of CE [20].

Religion especially being a Muslim was a risk factor in Kasese region (Table-3). This could be due backyard slaughter of livestock done during religious festival Idi fitri and Idi Aduha. This has been shown to be true among Muslim family clusters in China [22] North Africa and Middle East [33-36]. This was because whenever there were home slaughters dogs were fed on hydatid cysts from the offals. This finding agreed with earlier findings $[16,17]$ made in Kasese district.

From this study, it became apparent that CE was widespread in PAP areas in Uganda, requiring immediate attention. Being a pastoralist, female, increasing age, water source, dog ownership, and being a Muslim were found to be the risk factors. There was, therefore, a need to create awareness of the hazards of CE to the local communities in PAP areas. Furthermore, the local communities and health workers need to be educated about the risk factors promoting the occurrence of CE. CE screening and treatment units according to WHO standards [2] should be established in these areas. Best model(s) of carrying out CE screening and treatment needs to be identified and adopted. This study, therefore, serves as an entry point for this disease to be considered as a serious medical issue in Uganda so that a policy and strategic management plan for CE can be created.

\section{Conclusion}

In conclusion, being a pastoralist, a female, increasing age beyond 40 years, open spring water sources, dog ownership and being a Muslim were the risk factors for CE in PAP areas in Uganda.

\section{Authors' Contributions}

EO: Participated in research design; field data collection, management and analysis; manuscript development and revision. ALO: Study design, field data collection and reading of manuscript. EM: Study design and manuscript reading. PO: Study design, field data collection and analysis; and manuscript revision. MC: Study design, data collection and manuscript revision. LO: Study design, data collection and manuscript revision. FOI: Study design, field study and manuscript reading. LSA and FE: Study design and manuscript revision. MO: Developed overall CE study concept, participated in study design, field data collection, data analysis, manuscript development and revision. All authors have read and approved the final manuscript.

\section{Acknowledgments}

Authors thank the German Research Council (DFG) for funding this study through the CE in sub-Saharan Africa Research Initiative (CESSARi) project coordinated by Professor Peter Kern Ulm University Hospital, Germany. We also appreciate efforts made by Uganda's Ministry of Health Research Council, District Health Officers, Local Village Councils and Volunteer participants in facilitating the success of this study.

\section{Competing Interests}

The authors declare that they have no competing interests. 


\section{References}

1. WHO. The control of neglected zoonotic diseases, a route to poverty alleviation. Geneva: World Health Organization; 2006.

2. WHO. Echinococcosis. Fact Sheet. Geneva: World Health Organization; 2015.

3. Moro P, Schantz PM. Echinococcosis: A review. Int J Infect Dis 2009;13:125-33.

4. Macpherson CN, Spoerry A, Zeyhle E, Romig T, Gorfe M. Pastoralists and hydatid disease: An ultrasound scanning prevalence survey in East Africa. Trans R Soc Trop Med Hyg 1989;83:243-7.

5. Magambo J, Njoroge E, Zeyhle E. Epidemiology and control of echinococcosis in sub-Saharan Africa. Parasitol Int 2006;55 Suppl: S193-5.

6. WHO. Working to Overcome the Global Impact of Neglected Tropical Diseases. Geneva, Switzerland: WHO Press; 2010. Available from: http://www.apps.who.int/iris/ bitstream/10665/44440/1/9789241564090_eng.pdf. Last accessed on 24-12-2016.

7. Owor R, Bitakaramire PK. Hydatid disease in Uganda. East Afr Med J 1975;52:700-4.

8. Macpherson CN, Siefert L, Francis B, Kabuusu R, Butler B, Bakamanume B. Human cystic echinococcosis in Uganda. Int Arch Hydatid 2004;35:42.

9. Woodford MH. A survey of parasitic infestation of wild herbivores and their predators in Queen Elizabeth National Park, Uganda. Bull Epizoot Dis Afr 1976;21:263-71.

10. Ocaido M, Siefert L, Baranga J. Helminthic risks associated with mixed game and livestock interactions in and around Lake Mburo National Park, Uganda. Afr J Ecol 2004;42:42-8

11. Inangolet FO, Biffa D, Opuda-Asibo J, Oloya J, Skjerve E. Distribution and intensity of Echinococcus granulosus infections in dogs in Moroto District, Uganda. Trop Anim Health Prod 2010;42:1451-7.

12. Othieno E, Okwi A, Mupere E, Zeyhle E, Oba P, Chamai M, et al. Prevalence of cystic echinococcosis in selected pastoral and agro-pastoral districts of Uganda. Ann Clin Cytol Pathol 2016;2:1025.

13. Saint Martin GA, Larrieu E, Chiesa JC, Dapcich C, Martinez E. Ultrasound scanning as a screening technique for hydatidosis in developing countries. J Clin Ultrasound 1988;16:233-237.

14. Schantz PM, Wang H, Qiu J, Liu FJ, Saito E, Emshoff A, et al. Echinococcosis on the Tibetan Plateau: Prevalence and risk factors for cystic and alveolar echinococcosis in Tibetan populations in Qinghai Province, China. Parasitology 2003;127 Suppl: S109-20.

15. Li D, Gao Q, Liu J, Feng Y, Ning W, Dong Y, et al. Knowledge, attitude, and practices (KAP) and risk factors analysis related to cystic echinococcosis among residents in Tibetan communities, Xiahe County, Gansu Province, China. Acta Trop 2015;147:17-22.

16. Wang Q, Huang Y, Huang L, Yu W, He W, Zhong B, et al. Review of risk factors for human echinococcosis prevalence on the Qinghai-Tibet Plateau, China: A prospective for control options. Infect Dis Poverty 2014;3:3.

17. Nyakarahuka L, Lalobo-Oryema M, Kankya C, Siefert L, Ocaido M, Ejobi F. Knowledge, attitude and practices towards cystic echinococcosis in pastoral communities in Kasese district. Adv Trop Med Public Health Int 2012;2:32-9.

18. Luke N, Francis E, Micheal LO, Clovice K, Ludwig S, Micheal O. A survey of potential risk factors associated with cystic echinococcosis in pastoral communities in
Kasese distract, Uganda. Adv Trop Med Public Health Int 2013;3:10-24.

19. Yang YR, Ellis M, Sun T, Li Z, Liu X, Vuitton DA, et al. Unique family clustering of human echinococcosis cases in a Chinese community. Am J Trop Med Hyg 2006;74:487-94.

20. Oba P, Ejobi F, Omadang L, Chamai M, Okwi AL, Othieno E, et al. Prevalence and risk factors of Echinococcus granulosus infection in dogs in Moroto and Bukedea districts in Uganda. Trop Anim Health Prod 2016;48:249-54.

21. Akalin S, Kutlu SS, Caylak SD, Onal O, Kaya S, Bozkurt AI. Seroprevalence of human cystic echinococcosis and risk factors in animal breeders in rural communities in Denizli, Turkey. J Infect Dev Ctries 2014;8:1188-94.

22. Yang YR, Sun T, Li Z, Zhang J, Teng J, Liu X, et al. Community surveys and risk factor analysis of human alveolar and cystic echinococcosis in Ningxia Hui Autonomous Region, China. Bull World Health Organ 2006;84:714-21.

23. Assefa H, Mulate B, Nazir S, Alemayehu A. Cystic echinococcosis amongst small ruminants and humans in central Ethiopia. Onderstepoort J Vet Res 2015;82:E1-7.

24. Fotiou V, Malissiova E, Minas A, Petinaki E, Hadjichristodoulou C. Seroprevalence of $\operatorname{IgG}$ antibodies against Echinococcus granulosus in the population of the region of Thessaly, Central Greece. PLoS One 2012;7:e37112.

25. Torgerson PR, Karaeva RR, Corkeri N, Abdyjaparov TA, Kuttubaev OT, Shaikenov BS. Human cystic echinococcosis in Kyrgystan: An epidemiological study. Acta Trop 2003;85:51-61.

26. French CM. The age and sex distribution of hydatid disease in Turkana. East Afr Med J 1980;57:791-4.

27. Rottcher KH. Hydatid cysts in East Africa. East Afr Med J 1973;50:466-8.

28. Cooney RM, Flanagan KP, Zehyle E. Review of surgical management of cystic hydatid disease in a resource limited setting: Turkana, Kenya. Eur J Gastroenterol Hepatol 2004; 16:1233-6.

29. Blancas Mosqueda M, Herrera Esparza R, Rodríguez Padilla C, Tavizón García JP, Mercado Reyes M, Badillo Almaraz V, et al. Gender as a factor of susceptibility to infection in experimental hydatidosis. Rev Latinoam Microbiol 2007;49:31-7.

30. Wachira TM, Macpherson CN, Gathuma JM. Release and survival of Echinococcus eggs in different environments in Turkana, and their possible impact on the incidence of hydatidosis in man and livestock. J Helminthol 1991;65:55-61.

31. Macpherson CN. Epidemiology of hydatid disease in Kenya: A study of the domestic intermediate hosts in Masailand. Trans R Soc Trop Med Hyg 1985;79:209-17.

32. El Berbri I, Ducrotoy MJ, Petavy AF, Fassifihri O, Shaw AP, Bouslikhane M, et al. Knowledge, attitudes and practices with regard to the presence, transmission, impact, and control of cystic echinococcosis in Sidi Kacem Province, Morocco. Infect Dis Poverty 2015;4:48.

33. Gottstein B, Bettens F, Parkinson AJ, Wilson F. Immunological parameters associated with susceptibility or resistance to alveolar hydatid disease in Yupiks/Inupiats. Arctic Med Res 1996;55:14-9.

34. Altintas N. Past to present: Echinococcosis in Turkey. Acta Trop 2003;85:105-12.

35. Seimenis A. Overview of the epidemiological situation on echinococcosis in the Mediterranean region. Acta Trop 2003;85:191-5.

36. Nasrieh MA, Abdel-Hafez SK, Kamhawi SA, Craig PS, Schantz PM. Cystic echinococcosis in Jordan: Socioeconomic evaluation and risk factors. Parasitol Res 2003;90:456-66. 